\title{
THE USE OF ACCOUNTING INFORMATION FOR RISK ANALYSIS - OPTIONS IN CENTRAL REGION ENTITIES
}

\author{
Alina CIUHUREANU \\ “Nicolae Bălcescu” Land Forces Academy, Sibiu, Romania \\ alinaciuhureanu@yahoo.com
}

\begin{abstract}
Every decision poses risks, and it is necessary for them to be known. Some may be avoided, others may be diminished, and with others the management will need to become accustomed and avoided and are predominantly related to the external environment. For this reason, the risk can be approached as a variation of the results under the pressure of the environment of the activity. Based on these considerations, the paper addresses the risk in terms of its definition based on the literature and presents some essential aspects regarding the fundamental categories of risks from the point of view of managerial utility. Based on a selective scientific research carried out on a sample of entities in the Centre Region, the paper captures the degree to which managers are interested in capitalizing the accounting information for knowing the risks.
\end{abstract}

Keywords: risk, accounting information, performance, bankruptcy, management

\section{Introduction}

A Harvard Business Review Analytic Services study found that only 1 in 10 respondents said their executive management was extremely effective in creating a risk awareness culture, and only $40 \%$ considered there was proactive management of integrated risk at all organizational levels [1]. Thus, there is a need for risk management, the primary purpose of which is to give an organization the opportunity to achieve its objectives [2], as the unexpected part of income, resulting from unforeseen events, quantifies the real risk of the business. After all, if we get what we expect without doing anything, we would no longer talk about risk, uncertainty and performance.

\section{Risk in literature review}

Mihalcea R. and Androniceanu A. [3] define the risk as "a measure of the mismatch between different possible outcomes obtained in more or less favourable or unfavourable conditions."

In addressing International Standards on Auditing (see ISA No. 315 [4]), the business risk results from "significant circumstances, events, acts or omissions that can affect the entity in pursuing its objectives and pursuing the strategy, or setting out inappropriate goals and strategies." Referring to the importance of risk awareness, Rusu C. and Vişoiu I [5] said that "we take risks not to avoid dangers, but to gain benefits and win and by taking controlled and known risks, we live the beautiful and essential part of life every day." By studying the bibliographic references (see [6], [7], [8], [9], [10]), we identified without limitation the following risk categories: internal risk, external risk, financial risk, market risk, commercial risk (price risk, sale, transport risk), cost risk, technical risk, investment risk, contractual risk, business risk, portfolio risk, foreign exchange risk, natural risk, transfer risk, insurable risk, legal risk, business risk, political risk, country risk 
etc. Because, as it can be seen from the bibliographical references used, the literature deals thoroughly with the various categories of risks, we will present some essential aspects regarding the fundamental categories of risks from the perspective of the utility offered in management.

Economic risk is an expression of the flexibility of operating result influenced by fluctuations of elements such as electricity or gas charges, fuel prices, wages, raw material and material prices, competition, consumer purchasing power, items that are later reflected on the cost, the sales price and the quantities sold. The main indicator of analysis available to management is the profitability threshold. In order to assess the economic risk and the sensitivity of the factors, in management, on the basis of the accounting information, it is possible to carry out: analysis of the profit rate sensitivity in relation to the variation of the utilization rate of the production capacity; analysis of the sensitivity of the profit rate in relation to the change in the sale price of the product; the analysis of the sensitivity of the profit rate to the variation in the company's economic life; sensitivity analysis using the profitability threshold or the equilibrium point. Economic risk analysis is mainly driven by operating leverage. Depending on the values obtained, the conclusions show whether the entity is in an unstable situation (CA is higher than the ROI of less than $10 \%$ ), stable (10-20\%), comfortable (over 20\%).

The use of accounting information to determine financial risk by determining the financial leverage gives the management the opportunity to characterize the evolution of the result indicators according to the financial structure and the degree of indebtedness. Financial risk can also be appreciated through the BCG (Boston Consulting Group) and ADL (Arthur D. Little) models [11], linking profitability and financial needs with the product portfolio most commonly known, dilemmas, cash sources, millstones - or life stages.
Risk of bankruptcy (insolvency).Under Law $85 / 2014$, "insolvency is the situation ... characterized by the insufficiency of cash resources necessary for the payment of certain, liquid and enforceable against the company debts..." [12]. If the insolvency regulation was necessary, we consider that the use of accounting information for knowing the risk of insolvency is at least equally necessary, given that the studies in the field (see for example www.coface.ro) made by specialists based on the data published in BPI is the basis for this statement. For example, the number of companies that interrupted operations in the first half of 2018 is 74,442 , up $12 \%$ over the same period in 2017, with effects being reflected in creditor losses, unemployment and further repercussions at macroeconomic level [13], [14]. In the simplest form, from a financial perspective, insolvency, potentially followed by bankruptcy, is manifested by a high degree of indebtedness at the same time as a low solvency rate. This type of risk denotes the incapacity to pay outstanding debts, a result generated by the losses incurred through the activity that led to the full use of equity [15]. The risk of bankruptcy involves a multitude of factors, which is why a mere analysis of the net situation, indebtedness, solvency and results is not enough. As a response to the shortcomings of selfstanding indicators, specialists have developed the Score Method, also known as Score $\mathrm{Z}$, a linear function based on various variables. Based on this method, economic theory identifies several models such as: Altman, Alexandru Gheorghiu, BCR, Canon \& Holder, Rolland-Berger.

\section{Objectives and Hypotheses of the Selective Research}

The selective research, based on which the results are presented below, was elaborated on a sample of 301 entities from the Centre Region. The research objectives and hypotheses are presented in table no. 1 . 
Table 1 Objectives and hypotheses of research

\begin{tabular}{|c|c|c|c|}
\hline $\begin{array}{c}\text { Central } \\
\text { objective }\end{array}$ & $\begin{array}{c}\text { Main } \\
\text { hypotheses }\end{array}$ & Secondary objectives & Secondary hypotheses \\
\hline \multirow[t]{2}{*}{$\begin{array}{l}Q_{1} \text { Knowing the } \\
\text { entity's choices } \\
\text { on the } \\
\text { capitalization } \\
\text { of accounting } \\
\text { information for } \\
\text { risk analysis }\end{array}$} & \multirow{2}{*}{$\begin{array}{l}\boldsymbol{I P}_{\boldsymbol{I}^{-}} \text {Managers } \\
\text { are less } \\
\text { interested in the } \\
\text { use } \\
\text { accounting } \\
\text { information to } \\
\text { identify risks } \\
\text { and most often } \\
\text { financial risk is } \\
\text { being assessed. }\end{array}$} & $\begin{array}{l}Q_{1.1} \text { Analysing the extent } \\
\text { to which management is } \\
\text { interested in knowing the } \\
\text { risks according to the } \\
\text { category and field of } \\
\text { activity of the entities. }\end{array}$ & $\begin{array}{l}I S_{1}-\text { There is a direct } \\
\text { relationship between the } \\
\text { category of entities and the } \\
\text { interest in knowing the } \\
\text { risks. } \\
I S_{2}-\text { Industry entities are } \\
\text { most interested in knowing } \\
\text { the risks. }\end{array}$ \\
\hline & & $\begin{array}{l}\boldsymbol{Q}_{1.2} \text { Identifying } \\
\text { assessed bys } \\
\text { category. }\end{array}$ & $\begin{array}{l}\boldsymbol{I} \boldsymbol{S}_{3}-\text { Recognition of risk } \\
\text { information is dependent } \\
\text { on the category of entities. }\end{array}$ \\
\hline
\end{tabular}

\section{Research Results and Conclusions}

In order to identify the extent to which the managers of the entities are interested in the knowing the risks, we have formulated variable v62 in the questionnaire used for the operationalization of the research. For detailed analysis, we used the secondary objective $\mathrm{Q}_{1.1}$-Analysing the extent to which management is interested in knowing the risks according to the category and field of activity of the entities, making the associations $\mathrm{v}_{62}$ with $\mathrm{v}_{2}$ and $\mathrm{v}_{62}$ with $\mathrm{v}_{1}$. The processed responses are presented in Tables 2, 3 and 4 .

Table 2. Managers are interested in knowing the risks

\begin{tabular}{|r|l|r|r|r|}
\hline & & Frequency & Percentage & Valid percentage \\
\hline Valid & 301 & & & \\
\hline & to a very small extent & 41 & 13,62 & 13,62 \\
\hline & to a small extent & 63 & 20,93 & 20,93 \\
\hline & neither to a small, nor a large extent & 112 & 37,21 & 37,21 \\
\hline & to a large extent & 47 & 15,61 & 15,61 \\
\hline & to a great extent & 38 & 12,62 & 12,62 \\
\hline & & 301 & 100 & 100 \\
\hline Score & $\mathbf{2 , 9 3}$ Total & & & \\
\hline
\end{tabular}

Source: statistical processing

The data collected to identify interest in knowing the risks that may affect the continuity of activity reveals that the highest share of responses $(37.21 \%)$ is neutral, while only $12.62 \%$ and $15.61 \%$ of the respondents say that are very much and very interested in identifying the risks that can affect their business. The calculated score (2.93) reveals a general average interest of managers to identify risks as an opportunity to capitalize on accounting information. 
Table 3. Managers are interested in knowing the risks - analysis by category

\begin{tabular}{|c|c|c|c|c|c|}
\hline \multirow[b]{2}{*}{ Opinion } & \multicolumn{4}{|c|}{ Category } & \multirow{2}{*}{$\begin{array}{c}\text { Total } \\
\%\end{array}$} \\
\hline & micro & $\begin{array}{c}\text { small } \\
\text { company }\end{array}$ & $\begin{array}{l}\text { middle-sized } \\
\text { company }\end{array}$ & big company & \\
\hline \multirow{2}{*}{$\begin{array}{c}\text { to a very small } \\
\text { extent } \%\end{array}$} & 37 & 4 & 0 & 0 & 41 \\
\hline & 25,00 & 4,76 & 0,00 & 0,00 & 13,62 \\
\hline \multirow{2}{*}{$\begin{array}{c}\text { to a small extent } \\
\%\end{array}$} & 43 & 17 & 3 & 0 & 63 \\
\hline & 29,05 & 20,24 & 5,77 & 0,00 & 20,93 \\
\hline \multirow{2}{*}{$\begin{array}{c}\text { neither to a small, } \\
\text { nor a large extent } \\
\%\end{array}$} & 58 & 37 & 13 & 4 & 112 \\
\hline & 39,19 & 44,05 & 25,00 & 23,53 & 37,21 \\
\hline \multirow{2}{*}{$\begin{array}{c}\text { to a large extent } \\
\%\end{array}$} & 8 & 18 & 15 & 6 & 47 \\
\hline & 5,41 & 21,43 & 28,85 & 35,29 & 15,61 \\
\hline \multirow{2}{*}{$\begin{array}{c}\text { to a great extent } \\
\%\end{array}$} & 2 & 8 & 21 & 7 & 38 \\
\hline & 1,35 & 9,52 & 40,38 & 41,18 & 12,62 \\
\hline Score & 2,29 & 3,11 & 4,04 & 4,18 & 2,93 \\
\hline \multirow{2}{*}{$\begin{array}{r}\text { Total } \\
\%\end{array}$} & 148 & 84 & 52 & 17 & 301 \\
\hline & 100 & 100 & 100 & 100 & 100 \\
\hline
\end{tabular}

Source: statistical processing

Based on the combined "risk awareness"/ "entity category" analysis, we conclude that no category of companies has a majority percentage in the option "to a great extent", but again it is obvious that large entities $(76.47 \%)$ and medium-sized $(69.23 \%)$ are most interested in such opportunities in capitalizing accounting information. For medium-sized entities (69.05\%) and micro $(93.24 \%)$, most options fall into the "neither-nor - to a very small extent" range. Following processing, the $\boldsymbol{I S}_{\boldsymbol{1}}$ secondary hypothesis - There is a direct relationship between the category of entities and the interest in knowing the risks is confirmed.

Table 4. Managers are interested in knowing the risks - analysis by field of activity

\begin{tabular}{|c|c|c|c|c|c|}
\hline \multirow{2}{*}{ Opinion } & \multicolumn{4}{|c|}{ Field of activity } & \multirow{2}{*}{$\begin{array}{c}\text { Total } \\
\%\end{array}$} \\
\hline & commerce & industry & services & agriculture & \\
\hline \multirow{2}{*}{$\begin{array}{l}\text { to a very small } \\
\text { extent } \%\end{array}$} & 7 & 1 & 28 & 5 & 41 \\
\hline & 11,48 & 1,33 & 18,06 & 50,00 & 13,62 \\
\hline \multirow{2}{*}{$\begin{array}{c}\text { to a small extent } \\
\%\end{array}$} & 19 & 11 & 31 & 2 & 63 \\
\hline & 31,15 & 14,67 & 20,00 & 20,00 & 20,93 \\
\hline \multirow{2}{*}{$\begin{array}{c}\text { neither to a small, } \\
\text { nor a large extent } \\
\%\end{array}$} & 20 & 22 & 69 & 1 & 112 \\
\hline & 32,79 & 29,33 & 44,52 & 10,00 & 37,21 \\
\hline \multirow{2}{*}{$\begin{array}{c}\text { to a large extent } \\
\%\end{array}$} & 7 & 23 & 15 & 2 & 47 \\
\hline & 11,48 & 30,67 & 9,68 & 20,00 & 15,61 \\
\hline \multirow{2}{*}{$\begin{array}{c}\text { to a great extent } \\
\%\end{array}$} & 8 & 18 & 12 & 0 & 38 \\
\hline & 13,11 & 24,00 & 7,74 & 0,00 & 12,62 \\
\hline Score & 2,84 & 3,61 & 2,69 & 2,00 & 2,93 \\
\hline \multirow{2}{*}{$\begin{array}{r}\text { Total } \\
\%\end{array}$} & 61 & 75 & 155 & 10 & 301 \\
\hline & 100 & 100 & 100 & 100 & 100 \\
\hline
\end{tabular}

Source: statistical processing

From the analysis of the field of activity, we note that industry entities are most interested in identifying their risks, most of them $(54.67 \%)$ being very and very much interested, while service entities appear to be being the most disinterested, the majority share of $82.58 \%$ being distributed in the "neither-nor - to a very small extent" range. Most respondents in the agricultural sector are totally uninterested in this aspect. 
Conclusions lead to confirmation of the $\boldsymbol{I} \boldsymbol{S}_{2}$ secondary hypothesis - industry entities are most interested in knowing the risks.

Another aspect surprised by the research was the highlighting of risks assessed by entities. Even if they are not in a position to assess any risk that may arise during the course of the business, we believe that they should at least address the main risks of accounting information: economic, financial or bankruptcy risk. By formulating the operational variable v63, we sought to identify the types of risks we assessed in the entities. The secondary objective formulated $Q_{1.2}$-Identifying the risks assessed by the entity category was achieved by associating $v 63$ with $v 2$. The answers are given in Tables 5 and 6 .

Table 5. Risks assessed on the basis of accounting information

\begin{tabular}{|l|r|r|r|r|r|}
\hline & Mentioned & $\begin{array}{c}\text { Not } \\
\text { mentioned }\end{array}$ & Percentage & $\begin{array}{c}\text { Valid } \\
\text { percentage }\end{array}$ & $\begin{array}{c}\text { Total } \\
\%\end{array}$ \\
\hline - economic risk & 84 & 217 & 27,91 & 27,91 & 100 \\
\hline - financial risk & 102 & 199 & 33,89 & 33,89 & 100 \\
\hline - bankruptcy risk & 60 & 241 & 19,93 & 19,93 & 100 \\
\hline $\begin{array}{l}\text { - others, } \\
\text { which? }\end{array}$ & 37 & 264 & 12,29 & 12,29 & 100 \\
\hline $\begin{array}{l}\text { - none and we do not intend to, } \\
\text { why? }\end{array}$ & 128 & 173 & 42,52 & 42,52 & 100 \\
\hline - none, but we intend to, why? & 61 & 240 & 20,27 & 20,27 & 100 \\
\hline
\end{tabular}

Source: statistical processing

Table 6. Risks based on accounting information by entity category

\begin{tabular}{|c|c|c|c|c|c|}
\hline \multirow[b]{2}{*}{ Risk } & \multicolumn{4}{|c|}{ Category } & \multirow{2}{*}{$\begin{array}{c}\text { Total } \\
\%\end{array}$} \\
\hline & micro & $\begin{array}{c}\text { small } \\
\text { company }\end{array}$ & $\begin{array}{l}\text { middle-sized } \\
\text { company }\end{array}$ & big company & \\
\hline \multirow{2}{*}{$\begin{array}{c}\text { Economic risk } \\
\%\end{array}$} & 1 & 14 & 52 & 17 & 84 \\
\hline & 0,68 & 16,67 & 100,00 & 100,00 & 27,91 \\
\hline \multirow{2}{*}{$\begin{array}{c}\text { Financial risk } \\
\%\end{array}$} & 3 & 30 & 52 & 17 & 102 \\
\hline & 2,03 & 35,71 & 100,00 & 100,00 & 33,89 \\
\hline \multirow{2}{*}{$\begin{array}{c}\text { Bankruptcy risk } \\
\%\end{array}$} & 0 & 4 & 41 & 15 & 60 \\
\hline & 0,00 & 4,76 & 78,85 & 88,24 & 19,93 \\
\hline \multirow{2}{*}{$\begin{array}{c}\text { Others } \\
\% \\
\end{array}$} & 4 & 3 & 22 & 8 & 37 \\
\hline & 2,70 & 3,57 & 42,31 & 47,06 & 12,29 \\
\hline \multirow{2}{*}{$\begin{array}{c}\text { None and we do } \\
\text { not intend to } \\
\%\end{array}$} & 108 & 20 & 0 & 0 & 128 \\
\hline & 72,97 & 23,81 & 0,00 & 0,00 & 42,52 \\
\hline \multirow{2}{*}{$\begin{array}{c}\text { None, but we } \\
\text { intend to } \\
\%\end{array}$} & 34 & 27 & 0 & 0 & 61 \\
\hline & 22,97 & 32,14 & 0,00 & 0,00 & 20,27 \\
\hline Total & 148 & 84 & 52 & 17 & 301 \\
\hline
\end{tabular}

Source: statistical processing

The processing of collected data highlights, first of all, that a majority of $62.79 \%$ of respondents say they do not assess any type of risk. Of these, a $20.27 \%$ figure indicates that they intend to use the accounting information to identify the risks because they help identify the weaknesses of the business, allow for decisions before being too late, they are aware of the importance of this research tool, it is possible to improve the activity for the future development (the respondents have pointed out the necessity to obtain financing) etc. A share of $42.52 \%$ of those who say they do not assess the 
risks highlights that they will not do it, mainly because they consider it not useful (the negative influences come from the external environment and there is no control over them), the business goes well focused on areas where there is no competition (and we would add, for the time being), it entails additional costs, difficulty in analysing etc.

Concerning those who use the accounting information for risk analysis, $33.89 \%$ are interested in financial risk, $27.91 \%$ seek to know the economic risk and $19.93 \%$ consider that knowledge of the bankruptcy risk is opportune for management. It is also worth mentioning the percentage of $12.29 \%$ of those who mentioned that they are assessing other risks, which include the risk of price changes, the risk of insolvency, contractual risk, investment risk, exchange rate risk.

An analysis made according to the company's category reveals that all large and medium-sized entities assess the economic and financial risk and most of them are also interested in the bankruptcy risk. As we have already experienced before, unfortunately, to the opposite side there are the micro-entities, which, in a percentage of $72.97 \%$ declare they are not evaluating any kind of risk and are not interested in doing so in the future. With regard to small entities, the situation is somewhat better, $32.14 \%$ of them saying they do not yet value the accounting information for the risk assessment but have the intention of realizing it in the future, $35.71 \%$ declare that they assess the financial risk and a share of $16.67 \%$ channel their efforts to assess the economic risk. The data obtained leads to the validation of the secondary hypothesis $\boldsymbol{I} \boldsymbol{S}_{3}$ Valuation of the accounting information for knowing the risks are dependent on the category of entities.

Consequently, the hypothesis formulated before the research $\left(\boldsymbol{I P}_{\boldsymbol{1}}\right.$ - Managers are less interested in the use of accounting information to identify risks and most often assess financial risk) is partially validated because, in view of the interest shown for the general knowledge of the risks, the score obtained was of 2.93 which places the general opinion in the neutral zone.

\section{Final Conclusions}

The assessment of the potential impact of the risk may be limited by both the range of possible effects and the likelihood of recurrence of risk over a given period. Such complications must be provided by managers and a management attitude, but also permanent attention is needed. Unfortunately, from the selective research carried out, we have found that these are also evaluated to a small extent. Regarding the managers' interest in knowing the risks that may affect the continuity of the activity, we concluded that it manifests itself at an average level, emphasizing the direct relationship with the category of entities. The reality of using information for risk analysis is sad, with a majority of $62.79 \%$ of respondents saying they do not assess any risk. However, we have also noticed the $20.27 \%$ share of those who say they intend because it helps identify the weaknesses of the activity, it allows making decisions before it is too late, they are aware of the importance of this research tool, it allows to improve the activity for future development etc. A share of $42.52 \%$ of those who say they do not assess the risks highlights that they will not even do it, mainly because it feels not useful, the business goes well, focusing on areas where there is no competition (and we would add, for the time being), it entails additional costs, difficulty in analysing etc. of those who assess risk, most often focus on the financial one.

\section{References}

[1] *** Risk Management in a time of Global Uncertainty, a report by Harvard Business Review Analytic Services, 2011, available on line at https://hbr.org/resources/pdfs/tools/17036_HBR_Zurich_Report_final_Dec2011.pdf,acc essed January 2019. 
[2] Constantinescu, Dan Anghel; Dobrin, Marinică, Asigurarea şi managementul riscului, Bucureşti, Ed. Tehnică,1998, pp. 40-41 Mihalcea Radu, Androniceanu Armenia Management: fundamente, interferenţe, studii de caz, soluţii, Ed. Economică, Bucureşti, 2000, p. 317.

[3] Mihalcea Radu; Androniceanu Armenia, Management: fundamente, interferenţe, studii de caz, soluţii, Bucureşti, Ed. Economică, 2000, p. 317 International Standard on Auditing, No. 315, Identifying and Assessing the Risks of Material Misstatement Through Understanding the Entity and Its Environment (Identificarea și evaluarea riscurilor de denaturare semnificativă prin înțelegerea entității și a mediului său), available online at http:/www.ifac.org/system/files/downloads/a017-2010-iaasbhandbook-isa-315.pdf, accessed in January 2014.

[4] International Standard on Auditing no. 315 Identifying and Assessing the Risks of Material Misstatement Through Understanding the Entity and Its Environment, available online at http://www.ifac.org/system/files/downloads/a017-2010-iaasbhandbook-isa-315.pdf, accessed january 2019.

[5] Vișoiu Iulian; Rusu Costache, Implementarea managementului riscului la nivel organizaţional (ghid aplicativ), Bucureşti, Ed. Economică, 2010, p. 22 .

[6] Isaic-Maniu Irina, Măsurarea și analiza statistică a riscului în România, cap. 2, 3, 4, 5, available online at http://www.biblioteca-digitala.ase.ro/biblioteca/carte2.asp?id=206\&idb, accessed April 2015.

[7] Jucan N. Cornel, Managementul riscului în economia de piaţă, Sibiu, Casa de Presă şi Editură Tribuna, 2000, pp. 9-12.

[8] Dragotă Victor; Ciobanu Anamaria; Obreja Laura; Dragotă Mihaela, Management financiar. Vol. I Analiză financiară şi gestiune financiară operaţională, Bucureşti, Ed. Economică, 2003, pp. 262-263.

[9] Catană Adina, Patterns of risk in the retail business in Romania, Analele Universităţii "Constantin Brâncuşi” din Târgu Jiu, Seria Economie, No. 4/2010, pp. 59-63.

[10] Bogdan Ioan, Managementul riscului în afaceri între realitățile și cerințele lumii contemporane, Sibiu, Ed. Universității “Lucian Blaga” din Sibiu, 2009, pp. 67-71.

[11] Nicolescu Ovidiu, Verboncu Ion, Fundamentele managementului organizației, București, Ed. Universitară, 2008, p. 188.

[12] Legea nr. 85/2014 privind procedurile de prevenirea insolvenței și de insolvență, M. Of. nr. 466/25.06.2014, cu modificările şi completările ulterioare.

[13] ***Insolvenţele sunt la un minim al ultimilor zece ani însă pierderile generate creditorilor se află aproape de maximul ultimului deceniu, comunicat de presă Coface, 23.08.2018, available online at http://www.coface.ro/Stiri-Publicatii/Stiri/Insolventelesunt-la-un-minim-al-ultimilor-zece-ani-insa-pierderile-generate-creditorilor-se-aflaaproape-de-maximul-ultimului-deceniu, accessed march 2019.

[14] Guda Iancu, Studiul insolvenţelor România 2018, available online at www.coface.ro/content/download/161090/.../Coface-Studiul-Insolventelor-2018.pdf, accessed march 2019 Holt Gheorghe, Bankruptcy risk - central point in the financial accounting diagnosis, Analele Universităţii "Constantin Brâncuşi” din Târgu Jiu, Seria Economie, Nr. 3/2009, p. 325.

[15] Holt Gheorghe, Bankruptcy risk - central point in the financial-accounting diagnosis, Analele Universităţii “'Constantin Brâncuşi” din Târgu Jiu, Seria Economie, Nr. 3/2009, p. 325. 